\title{
Development of China Cross-border Electricity Supplier
}

\author{
Xiaoxia $\mathrm{Yu}^{1, \mathrm{a}}$ \\ ${ }^{1}$ Weihai Vocational College, Weihai, Shandong, 264210 \\ a email
}

Keywords: Cross-border Electricity Supplier, Development Trend, Internet Adoption

\begin{abstract}
In recent years, China's export growth rate of continuous decline, while the cross-border electricity supplier turnover but has maintained a strong momentum of growth. On the one hand, the domestic electricity supplier giants have the layout of the cross-border electricity supplier business; on the other hand, the traditional foreign trade enterprises in transition to collective cross-border electricity supplier. And from the point of view of the market space field of foreign trade, cross-border electricity supplier is ushering in a new "golden age." Restricting cross-border electricity supplier development bottleneck lies in policy, technology, logistics and settlement aspects. For the current existence of these problems, the relevant departments and the majority of the electricity business enterprises to adopt targeted measures, such as the introduction of supporting policies, the gradual improvement of the continuous strict market supervision system, cross-border payments and cross-border logistics system. So as to effectively protect the cross-border e-commerce development.
\end{abstract}

\section{Introduction}

After 2011, with the continuous development of the domestic electricity business, cross-border electricity supplier has a distinct branch gradually compelling. According to data from the Ministry of Commerce show that in 2013 China import and export value for the first time topped \$ 4 trillion, of which notably cross-border electricity supplier and export trade volume reached 3.1 trillion yuan (about 5057 billion US dollars), up 31.3\%; this means that in 2014 there are nearly 400 million international express parcels or the use of cross-border e-commerce international parcel 2 way exports and imports, nearly one billion of goods through cross-border electricity Suppliers are sold overseas. With the development of cross-border e-commerce model is expected in 2016 China's import and export volume of cross-border electricity supplier will grow to 6.5 trillion yuan. At the same time, large-scale import and export business more than just cross-border electricity supplier, Importers and small parcel business has made remarkable development. This cross-border transaction is directly to consumers, also known as "sea Amoy" 3 or "Shopping" 4. According to China Electronic Commerce Research Center data show that, in 2013, cross-border transaction size overseas purchasing more than 70 billion yuan, domestic buyers use direct sea Amoy consumption data also increased by $117 \%$, far higher than the domestic online shopping growth rate of $64.7 \%$.

\section{The Situation of Cross-Border Electricity Supplier in China}

Cross-border e-commerce transactions, referred to the cross-border electricity supplier. Can be understood as is the foreign trade electricity supplier, referring to belong to different customs territory of the subject transaction, by means of e-commerce will be the next line of import and export trade of goods on display, communication, negotiation and networking aspects of the final transaction and, ultimately, through cross-border logistics of the delivery of goods, completion of an international business transactions. Electronic trade, including goods, data transfer lines, cross-border electronic payment and electronic funds and cross-border logistics and freight documents and so on.

Cross-border electricity supplier in accordance with a large sales platform to distinguish, can be divided into B2B and B2C form 6 form 7. Through cash flow, profit model, profitability and other aspects of cross-border electricity supplier contrast China B2B and B2C modes, can be found in the 
future B2C model will achieve explosive growth, this model will occupy the Chinese market, more and more cross-border electricity supplier more share and become a new profit growth point of China's SMEs.

From the international market, development of economic globalization now become more and more deeply, the number of regional and bilateral free trade agreements increasing regional economic integration and trade liberalization also continued to promote international industrial transfer from processing and manufacturing sectors to the ends of the industrial chain extension, bring opportunities for China to extend the industrial chain, optimizing the feature configuration; the second is urbanization, industrialization process in developing countries and emerging economies accelerated economy is expected to maintain a rapid development, and open up new markets for the Chinese support; Third, technological innovation and new industries complement each other, the development of technology to accelerate industrial upgrading, so as to promote international division deepened to promote the development of intra-industry trade, the expansion of international trade in space.

\section{Several Major Trade Patterns of Cross-Border Electricity Supplier}

Press the object of trade points, can be divided into B2B websites, B2C website, C2C sites and 10 sites $\mathrm{O} 2 \mathrm{O}$ four. Namely, enterprise business-oriented platform for cross-border trade, cross-border business platform for end consumers, businesses face the ultimate consumer platform for cross-border trade, as well as the face of the final customer product line store experience internet. From the trade scale, the proportion of cross-border electricity supplier currently B2B transactions reached as much as $93.9 \%$, cross-border electricity supplier B2B transactions absolute dominance. This is mainly due to the order of magnitude larger B2B transactions, and more for the stability of orders, so the forecast in the next few years, B2B cross-border transactions is still the main electricity supplier.

From the category of goods sold, the cross-border sales of goods business enterprise type of basic auto parts, apparel, home and garden, 3C electronics, computers and accessories, jewelry and other logistics to facilitate small products, this year has also gradually to the automotive large homes and other big-ticket goods expansion trend. According to eBay data. This year on eBay's fastest growing platform followed by three categories: fashion, auto accessories and home gardening, and $71 \%$ of the big sellers are planning to expand the existing product categories, more than $64 \%$ of the planned extension of the big sellers to other product lines. One important means of cross-border expansion of their business electricity supplier, is expanding sales of product categories, which can contribute to cross-border commercial enterprises have more spending power to seize the online shopping population. With the impact of electronic commerce on people's daily lives continues to deepen and continue to penetrate, and logistics solutions innovative solutions and technological means of cross-border electricity supplier retailers will continue to expand product categories covered.

From the sales target market, for now the export of cross-border electricity supplier, the United States, Britain, Germany, Australia, is more representative of the mature markets, where customers are already familiar with cross-border online shopping, the higher the overall extent of regulation of commercial civilization local logistics support facilities in the next period of time is still the main providers of cross-border electricity export target market, and will still have a large room for growth. At the same time, a rising power of emerging markets is becoming a new cross-border electricity supplier industry retail outlet: 1 . Russia, Brazil, India and other countries of the local electricity supplier companies are not well developed, strong consumer demand, price Wumart products made in China Lim, in the market in these countries huge advantage. 2. The large number of companies are expanding Southeast Asian markets, Indonesia is the most populous country in Southeast Asia, the world's fourth largest populous, has great consumption potential, at present, eBay, Amazon, Rakuten and other electronic business platform giants are beginning to enter Indonesia market. 3. In Latin America, Eastern Europe, Africa and the Middle East and other regions, cross-border e-commerce and online shopping is still a relatively new concept for cross-border business 
enterprise, it is the need to spend more time and effort to reclaim and culture market.

\section{The Future of Cross-Border Electricity Supplier Bottlenecks and Strategies}

Cross-border B2B trade typically traditional lodgement, its cumbersome customs procedures, cross-border e-commerce so that the timeliness of the advantage of greatly reduced. At the same time cross-border online retail traded varieties, high-frequency characteristics have also relied heavily on air parcel, postal and courier. Relevant government departments in order to standardize the management of overseas purchasing activities, require all foreign express delivery companies use EMS. Clearance and delivery of parcels must be in accordance with trade customs clearance of goods, caused direct contradiction of traditional trade and modern customs clearance characteristics of cross-border online retail incompatible. No declaration when no more part of commercial enterprises import and export business, cross-border network of retail trade activities, can not be related to foreign exchange, tax rebates and other operations. In addition to customs clearance, tax, foreign exchange and other aspects, the cross-border sale and return also troubled electricity supplier is a major problem. E-commerce features determine the proportion of higher return, higher in some European and some other countries generally retail service levels unconditional return policy. Therefore, the rate of return of cross-border e-commerce has been a growing trend. However, due to the logistics involved in cross-border and customs clearance, return is difficult to have a smooth passage to return home. Moreover, the repair and return of goods due to the generally treated as imported goods in the present, the other needs to pay import duties, so that the burden of business enterprise is too large.

Compared to the rapid development of cross-border e-commerce, construction-related market supervision system has lagged, even showing a blank state. Our only "Internet Information Services" and a few other laws and regulations has been involved in the provision of cross-border e-commerce core transactions, taxation and consumer protection and so lack the necessary and reasonable standards. Market supervision system is too weak to give the false propaganda opportunity and counterfeit goods, illegal transactions have occurred even fraud. And the absence of appropriate intellectual property laws and regulations to constrain the environment, IPR violations is not stopped, the overseas consumer complaint rate is getting higher and higher. E-commerce platform eBay made relevant statistics shows that cross-border transactions Chinese sellers on eBay is completed, the average per 100 pen has 5.8 complaints, is the global average (2.5) twice as much. Some foreign commerce platform had to enact strict regulations to safeguard trade order against Chinese Seller: higher commission or harsher penalties. This has seriously affected China's foreign trade electricity supplier corporate image, is not conducive to creating an environment conducive to cross-border e-commerce activities in the international trade environment.

Usually several ways when the settlement of cross-border e-commerce electricity supplier: (1) opened multiple personal accounts. Some foreign trade electricity supplier a monthly turnover of hundreds of thousands of dollars, to avoid limiting the amount of foreign exchange, by opening multiple accounts to disguise the total increase of foreign exchange settlement. (2) dealing with the problem of foreign exchange through an underground foreign exchange intermediary. (3) use of a few areas of special foreign exchange policy does not limit the amount of settlement to settlement. Foreign trade electricity supplier for the current growing number of non-standard terms and do not facilitate the settlement of the Department, the need for the relevant administrative departments to take timely measures to improve and improve.

Because of cross-border e-commerce has a huge customer base overseas, but commercial enterprises in the process of cross-border transactions are often encountered and lost cargo clearance time is too long and some other column problems, a lack of business in this area in the past exchanges between China and relevant countries and cooperation, so that this problem has not effectively addressed. In response to this short board, attaches great importance to the Ministry of Commerce, began to actively expand consultations with relevant countries, and vigorously promote cross-border e-commerce rules, research and treaty-making, and gradually build up bilateral and 
multilateral cooperation mechanisms for international cross-border e-commerce from the system on the domestic electricity business enterprises to create conditions for cross-border e-commerce activities. When carrying out the relevant bilateral and multilateral FTA negotiations, our government actively consider domestic cross-border e-commerce development, rational use of the rules of the relevant international organizations, to effectively assist domestic enterprises to cope with e-commerce and cross-border trade activities produce disputes. Cross-border e-commerce as a cross-border business activities, inseparable from governments, which will vary between China and relevant countries increasingly deeper cooperation to be developed and improved.

Cross-border electronic business platform plays an important role. Compared with developed countries, China's development of cross-border electronic business platform is still enough, there is much room for development. Relevant government departments have also have a clear understanding, and the gradual introduction of specific support policies from the policy support and protection of all e-commerce platform to carry out cross-border e-commerce norms to better play their resources in the integration of domestic enterprises, docking and other aspects of the advantages of the international market. Actively support cross-border electronic business platform to foreign advanced electronic business platform and learn, to international standards as soon as possible, and then to carry out standardized operation, effectively improve service quality, summed up the electricity supplier for the domestic trading patterns. Through this series of policies to encourage and facilitate cross-border electronic business platform for future pace of development will be even greater, but the overall level will have a relatively large increase.

\section{Conclusion}

In summary, our cross-border e-commerce in order to seek better and faster development, sector policies and relevant to the needs of their own electricity supplier to improve simultaneously. Do a good job in the relevant laws and regulations, industry standards and standardized intelligence and other enterprise back-end logistics processes multiple links, in order to effectively protect the cross-border e-commerce development.

\section{References}

[1] Guan Peng. battles cross-border electricity supplier - the next era of disruptive business, Barbaric Pathfinder" 2015.2.

[2] Long Peng. China Market Development Report --2014 electricity supplier, electricity providers are doing what 2015, 1.

[3] AliExpress University, cross-border electricity supplier: Alibaba AliExpress Collection 2014.12.24.

[4] Ma Mei, Zhu Xiaoming. Pay Revolution: Third Party Payment 2014,1,16 Internet Age.

[5] Zhou Ning, Zhang Linglu. Foreign trade electricity supplier positioning: network business success 2014,6,1

[6] Post FTA, FTA get through customs, 2014, 5.

[7] Ministry of Commerce of China E-commerce Report (2013).

[8] money Yujuan. 2013 Cross-border electricity supplier of the golden age [J]. China Economic Information, (501). 